\title{
СОЦІАЛЬО-ПСИХОЛОГІЧНІ ХАРАКТЕРИСТИКИ І ЗАКОНОМІРНОСТІ ФОРМУВАННЯ ФЕНОМЕНУ САМООБМЕЖЕННЯ СУЧАСНОЇ МОЛОДІ
}

У статті визначено сочіально-психологічні характеристики і закономірності формування феномену самообмеження сучасної молоді. Показано, щзо сочіально-психологічний аналіз феномену самообмеження особистості дозволяє розглядати його як цілісний психологічний механізм, змістовним аспектом якого виступає власне ставлення, а динамічним - фіксована установка, проте психологічна природа й та роль, котру виконує означений механізм у життєдіяльності, варто упрозорити через поняття смислової регуляиії. Наголошується, щуо ставлення до самообмеження й самоорганізаиії є суб'єктивно забарвленим відображенням особистістю взаємозв'язків власних потреб з об'єктами та явищами світу, виступає чинником, щуо обумовлює поведінку молодої людини; це - суб 'єктивне ставлення, щэо утворює своєрідне ядро суб' сктивного світу особистості.

Ключові слова: сучасна молодь, самообмеження, самоорганізачія.

Постановка проблеми. Демократичні зміни, що відбуваються у суспільстві, потребують від психологічної науки зміщення акценту у вивченні регуляції поведінки із зовнішніх контролюючих інстанцій до вивчення внутрішніх суб' єктивних закономірностей особистісного й професійного контролю, власне схильності особистості до самообмеження.

Зміна тоталітарного режиму, що панував у нашому суспільстві багато десятиліть, призводить до заміни соціально-психологічної моделі суспільства, що, відповідно, утворює нову парадигму регуляції й контролю соціально-значущої поведінки особистості. Неможливість ефективного уніфікованого тотального контролю з боку зовнішніх структур у суспільстві нового типу, вимагає вивчення можливостей формування, розвитку й стабілізації систем внутрішнього контролю соціально-значущої поведінки особистості у всьому розмаїтті ії̈ індивідуальних проявів [2; 4].

В останні десятиліття відбувається трансформація предмета психологічних досліджень активності особистості, яка розглядається не стільки як адаптивна, спрямована на соціалізацію, соціальну адаптацію й відпрацьовування механізмів оптимального функціонування в рамках ідейно-ціннісної залученості, інтеріоризовану особистістю, скільки, становлення суб'єктності як феноменологічного втілення особистісного в людині. Таким чином, актуальність дослідження полягає в тому, що сучасні умови пропонують новий ракурс розгляду проблеми взаємодії людини й світу. Один з напрямків досліджень такої взаємодії полягає у вивченні психологічних характеристик і закономірностей внутрішнього контролю особистості як суб’єкта життєдіяльності [5; 6].

Аналіз останніх досліджень і публікацій. Феномени особистісного вибору, волі й відповідальності, персоналізації, надситуативної активності, стійкості особистості, індивідуалізації стають основою найцікавіших й фундаментальних досліджень психології останніх десятиліть (К. Абульханова-Славська, О. Асмолов, В. Петровський, В. Слободчиков, В. Чудновський, В. Зінченко, А. Налчаджян, Ш. Орлов, І. Котова й ін.).

Змін парадигмального погляду на такі категорії, як “активність”, “особистість”, “розвиток особистості”, “становлення особистості” призводить у 90-і роки до нового трактування співвідношення зазначених понять, що яскраво проявляється в сучасних дослідженнях (А. Петровський, В. Петровський, А. Маркова, І. Якиманська, Ю. Кулюткін, Г. Сухобська, С. Шеїн).

Проведений нами теоретичний аналіз показує, що зазначена проблема є найменш вивченою частиною загальної проблеми активності особистості, інтенсивне вивчення якої упрозорюється сьогодні. Як у вітчизняній, так і в зарубіжній психології відсутня цілісна концепція системи самообмеження особистості, немає iіi чіткого опису ні на феноменологічному рівні, ні на процесуальному. Разом з тим у сучасній психології накопичений багатий експериментальний матеріал у цій галузі, що вимагає свого узагальнення, перевірки й наукового осмислення. 
Мета статті - визначити соціально-психологічні характеристики і закономірності формування феномену самообмеження сучасної молоді.

Виклад основного матеріалу і результатів дослідження. Як відомо, індивідуальна самоорганізація кожної особистості на рівні самосвідомості може відкрити реальні можливості для виходу людини із кризи, для її самореалізації. Це можливо лише через усвідомлення й переживання своєї особистісної причетності до всього, що відбувається у світі, й насамперед до того, що відбувається із самою людиною [1; 3; 7]. Тому звернення до феномена самообмеження, до вивчення його взаємозв'язку з “образом Я” допоможе зробити більш глибоким наше розуміння особливостей розвитку особистості в сучасному суспільстві.

У контексті проведеного дослідження слід звернути увагу на такі поняття, як “самозаперечення” та “самозречення” й навіть “моральний мазохізм”, які дозволяють розкрити психологічну природу поняття “самообмеження”.

Отже, самозречення - практика навмисного утримання від задоволень, найчастіше застосовується тими, хто пропагує аскетизм, хто вважає, що жертвує поверхневими й тривіальними задоволеннями заради певної мети або відповідної психологічної переваги.

У рамках проведеного дослідження виявлення феномена самозаперечення розглядається як вираження кризи людського існування, процесу втрати сучасною людиною буттєвого саморозуміння в результаті становлення системи, що відокремлюється, від загальнолюдської діяльності.

Самозаперечення й самозречення як суттєві чинники неприйняття особистістю свого реального “Я” виявляють позитивні й негативні наслідки. Позитивні наслідки полягають у спрямованості особистості щодо радикальних змін та самозмінювань, внаслідок чого відбувається іiі розвиток. Негативні - пов'язані із становленням та закріпленням негативної “Я-концепції” й оформленням деструктивних аспектів, а саме: морального мазохізму, невротичного характеру, психопатологій та ін.

Вищою похідною від самообмеження виступає смирення. Це така форма свободи, що забезпечує людині, попри труднощі і перепони, умиротворення й спокій, а також допомагає вистояти перед будь-якими випробовуваннями долі.

Та, мабуть, найабсолютнішою, граничною мірою самообмеження є така форма свободи, як самозаперечення. Тобто людина за своєю волею відмовляється від свободи або максимально сама собі їі обмежує (наприклад, вияви альтруїзму, фанатизму, добровільного підкорення Богу, певному авторитету). Практично всі названі та інші подібні форми вияву свободи пов'язані з такою ії̈ обов'язковою формою, як відповідальність.

Однак слід проголосити, що людина, будучи істотою універсальною, здатною до самовизначення, самореалізації, самообмеження, є одночасно і вільною - для розуміння свободи теж не достатньо. Справа в тому, що всі ці властивості можуть реалізовуватись під примусом або за необхідністю, тобто бути ззовні причинно-зумовленими.

Отже, варто відокремити поняття “обмеження" та “самообмеження".

Оскільки суспільство постає як ієрархічна багаторівнева система, то обмеження варто аналізувати на будь-якому рівні, окрім того один рівень можна розглядати в якості обмеження стосовно іншого.

Зважаючи на вищевикладене, слід зробити висновок про те, як суспільна діяльність, практика створює власні обмеження у вигляді об'єктивованих результатів попередньої практики. Тобто аналіз суспільної практики має діалектичний характер, оскільки є як аналізом процесів, стримуваних подібними обмеженнями, так і процесів заперечення та зняття обмежень.

Перший рівень, на якому ми виявляємо обмеження, - це рівень нашої біологічної організації й фізичної структури оточуючого світу. На цьому рівні теорія повинна взяти до уваги ті закономірності, що призводять до формулювання природних законів i ïх застосування для того, щоб подолати обмеження біологічних й фізичних властивостей. 
Теорія також повинна досліджувати, як успішне подолання обмежень породжує нові обмеження. Один із прикладів - процес ядерного синтезу, застосування якого для одержання енергії обмежене труднощами досягнення високих температур, необхідних для реакції.

На противагу повсякденним уявленням про те, що “закони природи” примушують нас поводитися так, а не інакше, варто відзначити, що закони не роблять нічого подібного. Закони природи не змушують нас здійснювати певні дії, але, скоріше, чинять перепони в процесі, коли нам необхідно виконати їх, що не виключає волі людського вибору. Згідно із законом всесвітнього тяжіння, ми не можемо літати, не застосовуючи технічних засобів, однак закон не може перешкодити людині викинутися з вікна, якщо вона так вирішила i готова до наслідків. Це важливо підкреслити, оскільки на всіх рівнях обмежень, які ми аналізуємо, існує певна свобода вибору за умови, що ми готові прийняти його наслідки. Положення про “свободу вибору” відіграє важливу роль і має серйозні наслідки як теоретичного, так і морального плану.

Переходячи від світу фізичного до світу соціального, ми виявляємо все більше складнощів і усе менше законів. Другий рівень обмежень - рівень соціальної системи. Існуючі економічні, соціальні, політичні й культурні процеси та їх внутрішня динаміка встановлюють межі наших можливостей діяти. І знову дане твердження має силу за умови, що ми готові відповідати “правилам гри” і вважати санкції проти певних типів дій заборонними. Наявні відносини власності, владні відносини й суспільний поділ праці, правові норми, традиційний порядок дій, звичаї й успадковані думки, також як і приналежність до статі, класу, етнічної групи, - усі вони разом складають заборонні й обмежувальні умови. Їх можна підсумувати, сказавши, що ми з'являємося на світ - у соціальну систему, котра вже склалася й характеризується згаданими суспільними відносинами й процесами, котрі обмежують нашу волю. Вочевидь, непотрібно говорити, що як індивіди ми маємо певну свободу вибору, на яку вказують такі феномени, як злочинність, військові перевороти, контркультура тощо.

Теорії, що аналізують проблеми обмежень на цьому рівні, - це теорії соціологічного й економічного плану. На третьому рівні ми маємо справу 3 обмеженнями 3 боку організацій, у яких живемо й працюємо: родини, підприємства, добровільні громадські об'єднання. Тут має прояв обмеження двох типів: по-перше, існуючий поділ праці перешкоджає змінам. Більше того, розподіл влади й авторитету, завдяки процесам другого рівня, має прояв у повсякденному функціонуванні даних організацій. Будучи включеними в ієрархічну організаційну структуру, її члени обмежені у своїх діях і найчастіше змушені діяти всупереч своїй меті або цілям, яким суспільство загалом надає більшу цінність.

По-друге, у всіх цих організаціях існують правила й норми, що обумовлені як цілями й діяльністю подібних організацій, так і пов'язані з використанням ресурсів, що перебувають у розпорядженні організацій. Особливий інтерес у даному контексті викликають робочі місця. У суспільстві, мабуть, не існує іншої сфери, де теорії мотивації використовувалися би настільки широко, як при поясненні того, чому люди працюють або не працюють і як стимулювати їх до праці.

Складність аналізу трудових відносин визначається самою організаційною структурою багатьох робочих місць: вона більш-менш авторитарна, за структурою команд і односпрямованими каналами комунікації схожа на військову. У демократичному суспільстві, де люди привчені ухвалювати демократичні засоби й цілі як свої власні й прагнути до них, реальний досвід, що утворюється на робочому місці, суперечить офіційно прийнятим цілям суспільства і тому слугує обмеженням його автономії.

Звернемося до четвертого рівня обмежень - рівня міжіндивідуальних дій і взаємодій. На цьому рівні зустрічаються обмеження двох типів: по-перше, обмеження, зумовлені взаємодією при врахуванні формальних правил і запропонованих ролей (наприклад, взаємодія між військовослужбовцями різних звань) або викликаних взаємодією, на яку впливають положення й престиж взаємодіючих індивідів (наприклад, взаємодія парафіянина й священика, лікаря й пацієнта). По-друге, у самому процесі комунікації 
зустрічаються обмеження всіх рівнів, оскільки всі види вербальної комунікації й усі тексти варто сприймати та розуміти у конкретному контексті.

До четвертого рівня належать теорії комунікації, що мають справу з проблемами гносеології, і соціально-психологічні теорії взаємодії.

На п’ятому й останньому рівні індивід сам встановлює для себе обмеження, хвилюється, не вірить у свої сили або не знає, як подолати ці перепони. А до фактичних обмежень, що виходять із критичного аналізу ситуації діючим суб'єктом, можуть додаватися обмеження, існуючі завжди у вигляді думки діючого суб'єкта про себе й свої здібності. Доки діючий суб' єкт не зважується діяти всупереч накладеним на себе обмеженням, останні будуть перешкоджати надбанню ним досвіду, який змінив би його самооцінку. На цьому рівні психологічна теорія цілком адекватна.

Самообмеження - це здатність узгоджувати прагнення своєї волі з обставинами, які викликані такими ж прагненнями інших воль або закономірностями природи. Така здатність часто сприяє гартуванню в людині високих духовних і фізичних властивостей.

Отже, суттєвими ознаками феномена самообмеження є часткова втрата змісту, суб'єктності й особистісної ідентичності; взаємозв'язок феномена самообмеження з “образом я” особистості носить взаємодоповнюючий характер. Змістовні характеристики явища самообмеження співвідносяться 3 когнітивною й афективно-емоційною складовими “образу Я”; специфіка співвідношення феномена самообмеження з “образом Я” особистості проявляється в наявності різних типів “образу я".

Певними видами самообмеження можна вважати такі форми, як релігійний аскетизм, вегетаріанство або самообмеження у їжі, речах та інші.

Основним психологічним змістом феномена самообмеження виступає значеннєвий (екзистенціальний) вакуум, наслідком якого є неприйняття людиною самої себе. Базовими ознаками феномена самообмеження $\epsilon$ часткова втрата особистістю: почуття усвідомлення власного життя, переживання суб'єктності.

Дані ознаки одночасно є не тільки змістовними, але й операційними, що роблять можливим практичне дослідження цього феномена і його взаємозв'язок з “образом Я” особистості.

Феномен самообмеження негативно позначається на особистісному рівні у вигляді негативного самоставлення до існуючого “образу Я” і у вигляді формування усталеного “зовнішнього Я”.

Явище самообмеження пов'язане з “образом Я” особистості (його оцінково-афективною складовою і меншою мірою - когнітивною складовою “образу Я”). Співвідношення цих феноменів носить взаємодоповнюючий характер.

Співвідношення феномена самообмеження з “образом Я” презентовано в наявності трьох типів “образу Я”:

- автентичний (“образ Я”, для якого характерно позитивне самосприйняття, гнучкість когнітивної складової без самовідданості);

- власне самообмеження (“образ Я”, що характеризується негативним самосприйняттям);

- самовідсторонення (“образ Я”, неконгруентний за своєю природою, що поєднує в собі суперечливі, але не повною мірою усвідомлювані характеристики).

Самообмеження може носити не тільки негативний, але й позитивний характер, стимулюючи особистісні зміни через заперечення старого “образу Я”.

У процесі самоусвідомлення особистістю самої себе в поєднанні з одночасним подоланням таких аспектів, котрі не задовольняють, відбувається іiі самоорганізація. Варто відзначити, що самоорганізація особистості неможлива без взаємозв'язку із такими структурними елементами особистості, а саме: самовизначенням, самообмеженням й самоподоланням, самопрезентуванням та самоусвідомленням, самокеруванням й самоздійсненням. 
Самоорганізація особистості - здатність до інтегральної регуляції природних, психічних, особистісних станів, якостей, властивостей, здійснювана свідомістю вольовими й інтелектуальними механізмами, що проявляється в мотивах поведінки й реалізована в упорядкованості діяльності й поведінки. Самоорганізація - це узгодження, підпорядкування, створення індивідуально-оптимальної особистісної й психічної системи; показник особистісної зрілості. Самоорганізація може бути виражена в різному ступені, вона не властива інфантильним суб' єктам, тобто тим людям, які в процесі індивідуального розвитку не мали умов для повноцінного становлення механізмів саморегуляції. Самоорганізація у них не набула цілеспрямованості, усвідомленості, контрольованості.

Отже, самовизначення завершує необхідне для конкретного акту практичної діяльності пізнання особистістю її сутнісних сил і в рамках практичного блоку самоорганізації особистості як системи передбачає самообмеження (процес фільтрації можливих у даних конкретних умовах дій) та самовповноваження. Самообмеження особистості означає вибір людиною однієї потреби для актуального задоволення. Особистість обирає певну сферу діяльності, в якій може предметно реалізувати власні сутнісні сили, але водночас несе відповідальність перед собою та суспільством у цілому за відмову від багатьох інших варіантів самореалізації (принаймні в даний момент).

Далі практичний блок самоорганізації особистості містить таку послідовність взаємопов'язаних процесів (самовповноваження, самопрограмування, самовдосконалення, самоактуалізація, самореалізація). Призначивши себе на певну діяльність, людина усвідомлює іiі кінцеву мету (тобто на цьому етапі визначається аттрактор) і проектує способи іiі досягнення. Це означає процес самопрограмування - вироблення ідеального образу свого життя через свідоме і цілеспрямоване планування власної діяльності.

У ході самовповноваження потреба переростає в інтерес, відбувається вибір людиною деякого шляху розвитку і свідоме призначення нею себе на певний вид діяльності. Вміння утриматися від дії або діяти в потрібний момент не менш важливе для розвитку особистості, ніж власне якісна визначеність її сутнісних сил.

Суперечності між ідеальним образом і реальними можливостями людини спричинюють самовдосконалення - діяльність, спрямовану на виправлення самою особистістю усвідомлених недоліків у структурі власних сутнісних сил. Це здійснюється через самотренування і самоосвіту. Самотренування як діяльність із підвищення ефективності функціонування сутнісних сил за допомогою повторюваних дій виступає напруженою працею, кінцева мета якої - якісно виконувати те, що людина хоче зробити. Самоосвіта це діяльність із самостійного підвищення кваліфікації, рівня власної освіченості за рахунок свідомого розширення спектру своїх можливостей. Цей процес передбачає самовиховання (свідоме впорядковування існуючої структури сутнісних сил відповідно обраній меті) та самонавчання як діяльність із отримання нових знань без допомоги сторонньої особи, що навчає.

Процеси самовдосконалення спрямовані на підвищення якості впорядкованої структури сутнісних сил і сприяють послідовному зближенню їх для задоволення нагальної потреби. Подальший напрямок цілісного процесу самоорганізації визначається третім фактором розвитку - селектором, яким стосовно особистості як дисипативної системи виступає принцип стійкості, первісної необхідності порядку. Пошук стійкості відіграє роль природного добору і спрямовує сутнісні сили особистості у заздалегідь визначеному напрямку.

Подальшим етапом є самоактуалізація особистості - процес максимальної концентрації сутнісних сил для наступної ефективної діяльності в напрямку обраної мети. Від розуміння власних одиничних здібностей через прийняття на себе відповідальності людина в процесі самоактуалізації отримує єдність сутнісних сил, здатну до діяльності з утворення другої природи. 
Таке максимальне злиття сутнісних сил є необхідною передумовою і запорукою ефективного здійснення процесу самореалізації особистості. Не погоджуємось 3 поширеним тлумаченням індивідуальної самореалізації як свідомого, цілеспрямованого процесу. Самореалізація особистості завжди свідома тільки в широкому смислі - тому, що людина володіє свідомістю.

Тому в найзагальнішому вигляді процес самореалізації особистості можна визначити як об’єктивацію її сутнісних сил. Її джерелом є фундаментальна потреба особистості в самореалізації, механізмом виступає діяльність, а значення для сукупного процесу самоорганізації полягає в гармонійному включенні особистості до ієрархічно вищих систем природи, суспільства, всієї об'єктивної дійсності.

Існують різні типи обмежень, тому значення терміна залежить від контексту. На кожному рівні аналізу обмеження слід розглядати в конкретній ситуації.

Кожний рівень аналізу вимагає свого теоретичного підходу. Як вказувалося вище, на другому рівні аналізу слід застосовувати соціолого-економічні теорії; на третьому - у спектрі теорій організації психологія мотивації повинна бути замінена теорією організаційних обмежень; на четвертому рівні теорії соціальної психології й теорії комунікації; на п’ятому рівні необхідний аналіз за допомогою психологічних теорій. На противагу теоріям мотивації, варто запропонувати низку теорій, адекватних аналізу на кожному конкретному рівні й аналіз будь-яких проблем, що виникають у конкретному контексті. У поясненні явищ дійсності загальним для цього набору теорій стало поняття людської дії й обмежень дії.

Відчуження - це втрата людиною почуття власної суб'єктивності в спілкуванні зі значущими іншими, втрата ідентичності, а також роз'єднання із самим собою й своїм психічним досвідом. Позиція самовідчуження - це відчуття неповноти, обмеженості, ущербності свого “Я”, супроводжуване негативними емоціями.

Відчуження - феномен, що несе, не тільки негативні, але й позитивні особистісні й соціальні функції. Відчуження - різнопланове, динамічне явище, що має певну структуру.

На основі теоретичного аналізу виокремлені основні інваріанти вживання поняття “самообмеження", які поєднує ідея втрати розуміння особистістю самої себе. Найбільш продуктивною, $з$ погляду вивчення й розуміння феномена самообмеження, є теорія ідентифікації - відокремлення, у якій самообмеження виступає як результат крайніх форм ідентифікації (злиття) і відокремлення (відчуження). На теоретичному рівні була виявлена можливість позитивного впливу самообмеження на “образ Я” особистості і їі розвиток у цілому.

Висновки. Самообмеження - це феномен, який характеризується відокремленням особистості від власного “Я” або окремих його складових (“образу Я”, “рефлексивного й екзистенціального Я”, емоцій, потреб). Найбільш значимою категоріальною ознакою самообмеження виступає втрата змісту як зникнення особистісно значимих зв'язків індивіда із собою і світом. Суттєвою ознакою самообмеження також виступає втрата суверенності, яку ми розглядаємо як форму суб'єктності особистості.

Соціальна самоорганізація формується упродовж життя під впливом соціального середовища, системи виховання, предметно-практичної та особистісно-рольової діяльності людини. Соціальна самоорганізація передбачає процес самопізнання, самовизначення, саморозвитку та самореалізації. Вона має вирішальний вплив на формування світогляду й морально-етичних переконань, на практичний вияв моральних почуттів.

Самоорганізація сучасної молоді полягає у цілеспрямованості, активності, обгрунтованості мотивації та плануванні діяльності, самостійності й швидкості прийняття рішень, оцінюванні наслідків праці, почутті обов'язку.

1. Катаєв С. Трансформація сучасного українського суспільства: постмодерністський контекст. Людина $i$ політика. 1999. № 3. С. 29-32.

2. Кузьмін М. В. Самоорганізація та соціоеволюція. Філософська і соціологічна думка. 1994. № 9-10. С. 99133. 
3. Лушин П. В. Два виміри принципу “не нашкодь” та кодекс екологічності. Практична психологія в системі вищої школи : монографія / за ред. Т. В. Бушуєвої, С. О. Ставіцької. Київ : НПУ імені М. П. Драгоманова, 2012. С. 38-53.

4. Максименко С. Д. Основи генетичної психології. Київ : Інститут психології ім. Г. С. Костюка, 1998.298 с.

5. Павловський М. А. Стратегія розвитку суспільства: Україна і світ. Київ : Техніка, 2001. 312 с.

6. Психологія особистості : словник-довідник / за ред. Г. Г. Горностая, Т. М. Титаренко. Київ : Рута, 2001. $320 \mathrm{c}$.

7. Савчин М. В. Духовний потенціал людини. Івано-Франківськ : Плай, 2001. 204 с. 